\title{
Fat deterioration in deep fat frying of «french fries» potatoes at restaurant and food shop sector
}

\author{
By L. Masson *, P. Robert, M. Izaurieta, N. Romero and J. Ortiz \\ Departamento de Ciencia de los Alimentos y Tecnología Química. Facultad de Ciencias Químicas y \\ Farmacéuticas, Universidad de Chile. Casilla 233. Santiago 1. Chile.
}

\section{RESUMEN}

Deterioro de materias grasas usadas en fritura de patatas «french fries» en el sector de restaurantes y pequeños establecimientos.

El objetivo de este trabajo fue conocer el deterioro de la materia grasa empleada en el proceso de fritura de patatas tipo "french fries" en el sector de restaurantes y pequeños establecimientos en Santiago (Chile) antes de que la reciente legislación chilena fuera oficial. El 96 $\%$ de las muestras correspondió a aceites vegetales poliinsaturados, el $76 \%$ contenían más de un $2 \%$ de ácido linolénico y el $23 \%$ del total de las muestras presentó más del $25 \%$ de compuestos polares.

Para predecir el porcentaje de compuestos polares, se desarrollaron ecuaciones que para el aceite de soja y mezcla soja-canola, incluyeron la viscosidad o los dienos conjugados mientras que para el aceite de girasol se consideró la viscosidad y los ácidos grasos libres.

El aceite de girasol mostró una distribución diferente de las especies alteradas que conforman la fracción de compuestos polares, en comparación al aceite de soja y mezcla soja-canola, presentando estos últimos significativamente una más elevada alteración termoxidativa.

Entre los tests evaluados se recomienda el ensayo de Oxifrit como prueba rápida para el control práctico del deterioro de grasas de fritura.

PALABRAS-CLAVE: Alteración termooxidativa - Compuestos polares - Grasa de fritura - Hidrólisis - Patatas «french fries».

\section{SUMMARY}

Fat deterioration in deep fat frying of «french fries» potatoes at restaurant and food shop sector.

The objective of this work was to know the deterioration of fats employed in deep frying of "french fries" potatoes at restaurant and food shop sector in Santiago (Chile), before the recent Chilean legislation became official. $96 \%$ of the samples corresponded to polyunsaturated vegetable oils, $76 \%$ had more than $2 \%$ linolenic acid and $23 \%$ of total samples contained more than $25 \%$ of polar compounds.

To predict the percentage of polar compounds, equations were developed: for soybean oil and mix soybean oil-canola the equation included viscosity or conjugated dienoic acids, while for sunflower oil viscosity and free fatty acids were considered.

Sunflower oil, presented a different pattern of the altered groups that comprise the fraction of polar compounds, as compared with soybean and mix soybean-canola oils, these latter two showing significantly higher thermoxidative degradation.

Among the diagnostic tests assayed, Oxifrit is recommended as a quick test for practical deterioration control.

KEY-WORDS: "French fries» - Frying fats - Hydrolysis - Polar compounds - Thermooxidative alteration.

\section{INTRODUCTION}

Deep fat frying process (DFFP) is quite common today at commercial level mainly in fast food restaurants, food shops and snack industries. Fried products have a great acceptance by people all age, but mainly by children and youth, which has led to an important increase in their consumption all around the world. It is known that fat may be damaged during the frying process, at different levels, depending on the type of fat used, the fried product, time and temperature used, batch or continuous process, etc., resulting in a complex mixture of oxidized and polymeric fatty materials. The possible health risks involved in the consumption of heated and/or oxidized fats as predisposition to atherosclerosis, mutagenic and carcinogenic action of heated fats has been reviewed and commented (Kubow, 1990). With the purpose to assure the population that safe foods are being prepared and consumed through DFFP, a great deal of research has been done in the analytical and nutritional contexts, although few papers have focused on direct surveys to evaluate the real situation of frying practice (Sebedio et al., 1987; Al-Kahtani, 1991; Dobarganes y Márquez-Ruiz, 1995a).

A number of authors (Artman, 1969; Alexander, 1978; Chang et al., 1978; Grandgirard, 1980; Combe and Constantini, 1978; Márquez-Ruiz et al., 1993) have done research trying to identify the compounds formed, their absorption and biological importance. A good agreement among these publications is found 
related to the new compounds that appear: volatile, which are more involved in the flavor deterioration of the fatty material, and non volatile such as oxygenated monomers, polymers and cyclic compounds, of different polarity, with or without oxygen. These last ones, non-volatile, are essential from the physiological point of view, because they stay in the fat and they are incorporated in the fried food. About methodology, the traditional chemical and physical indices for measuring the different changes produced in the heated oil, such as free fatty acids, peroxide value, iodine number, carbonyl compounds, color, smoke point, viscosity, non-urea adducts, dielectric constant, conjugated dienoic and trienoic acids, etc., are still widely used (Billek, 1978; White, 1991), but they provide only a partial measurement of oil deterioration. Direct evaluation of the compounds formed has been attained by gas liquid chromatography, to determine cyclic monomers and combination of adsorption and size exclusion high performance liquid chromatography, that permits to separate and to quantify oxidized and polymeric groups of compounds (Grandgirard et al., Juillard, 1987; Dobarganes et al., 1988; Dobarganes et al., 1989; Waltking and Wessels, 1981; Márquez-Ruiz et al., 1990; Arroyo et al., 1992).

To protect the customers, regulations, recommendations and practical guidelines have been adopted in different countries (Firestone, 1996; Reglamento Sanitario de los Alimentos, Chile, 1997). Most of them are related to limitations of free fatty acids value around $1-2,5 \%$, polar compounds between $25-27 \%$, oxidized fatty, acids insoluble in petroleum ether of $1 \%$, dimeric and polymeric triglycerides of $10 \%$, smoke point not below $180{ }^{\circ} \mathrm{C}$ and restriction to frying vegetable oils with less than $2 \%$ linolenic acid. Also, some quick colorimetric tests have been considered as useful practical methods for routine control of heated fats at retail establishments and fast foods chains, mainly Fritest, Oxifrit and Perevalov, (Croon et al., 1986; Dobarganes, 1995b; Skrökki 1995).

The aim of this work was to approach a first evaluation of the situation of DFFP in Chile, before the local legislation was official, at small and middle size restaurant and food shop sector, mainly dedicated to prepare and to expend french fries potatoes, one of the most popular fast food. Traditional and specific techniques to evaluate the deterioration of the fats and oils were used, and the results were compared with national and international regulations. Relationships between the fatty acid composition of the vegetable oil used and the deterioration components produced were examined. Correlation coefficients between percentage of polar compounds, free fatty acids, conjugated dienoic acids, and viscosity were determined. Additionally, Fritest, Oxifrit, and Perevalov tests were checked to determine if they could be recommended as routine «in situ» tests at retail points.

\section{EXPERIMENTAL}

\subsection{Sampling}

Eighty small and middle size restaurants and food shops where french fries potatoes were prepared for retail expenditure in Santiago (Chile), were selected following standard sampling methods (Normas Chilenas, 1978, 1994). The eighty samples were taken directly from the fryer batch type at the moment that french fries potatoes were being prepared. Samples were codified and maintained at $-30^{\circ} \mathrm{C}$ in hermetic dark glass bottles completely full, until they were analyzed. Large fast foods chains were not included, and they will be considered in other specific work.

\subsection{Methods}

Fatty acid composition was determined by GLG using a HP 5890 FID detector, capillary column fused silica BPX70, $50 \mathrm{~m}, 0.25 \mu \mathrm{m}$ film, temperature programmed between $160-230^{\circ} \mathrm{C}$, rate of $2^{\circ} \mathrm{C} / \mathrm{min}$, hydrogen as carrier, using reference fatty acids methyl esters (FAME) from Sigma and Merck for identification. FAME were prepared with sodium methylate (AENOR, 1991). Free fatty acids (FFA), peroxide value (PV), conjugated dienoic acids (CDA), were determined according to Ac 5-41; Cd 8-53; Til a-64 respectively (AOCS, 1993). For viscosity (Vs), a Brookfield viscosimeter model LVT with adapter ultra low viscosity at $6 \mathrm{rpm}, 40 \pm 1{ }^{\circ} \mathrm{C}$ was employed. For total level of polar compounds (PC), IUPAC method 2.507 was used (IUPAC, 1987). Further, distribution in triglyceride polymers (TGP), triglyceride dimers (TGD), oxidized triglyceride monomers (oxTG), diglycerides (DG) and free fatty acids (FFA) which comprise the polar fraction was determined by size exclusion high performance liquid chromatography (SEHPLC), (Dobarganes, 1988) using a Merck Hitachi liquid chromatograph with refractive index detector. Two 100 and $500 \mathrm{~A}^{\circ}$ Ultrastyragel columns $25 \mathrm{~cm} \times 0.77 \mathrm{~cm}$ inner diameter, were connected in series, operating at $35^{\circ} \mathrm{C}$, mobile phase was tetrahydrofuran at a flow rate of 1 $\mathrm{ml} / \mathrm{min}$. Sample concentration was between 15 and $20 \mathrm{mg} / \mathrm{ml}$ in tetrahydrofuran. Quick tests as Fritest and Oxifrit (Merck) and Perevalov (reagents prepared at the laboratory) were also assayed.

\subsection{Data Analysis}

Correlation between experimental data and equations of regression models were established. ANOVA followed by Duncan test was used for comparing alteration species, (López-Planes, 1994; Bender, Douglass and Kramer, 1982). 


\section{RESULTS AND DISCUSSION}

The results presented correspond to the total samples analyzed $(n=80)$ and were distributed per vegetable oil. Table I shows a summary of the fatty acid composition. Total saturated, monounsaturated and polyunsaturated fatty acids were listed, along with specific contents of linoleic (C18: 2) and linolenic (C18: 3 ) acids.

Table I

Fatty acid composition of vegetable oils used in small and middle size restaurant and food shop sector to prepare french fries potatoes (\% methyl esters)

\begin{tabular}{|c|c|c|c|c|c|c|c|c|}
\hline \multirow{2}{*}{ Fatty Acid [\%] } & \multicolumn{2}{|c|}{$\begin{array}{c}\text { SBO } \\
n=39\end{array}$} & \multicolumn{2}{|c|}{$\begin{array}{c}\text { MSBO/CANOLA } \\
n=22\end{array}$} & \multicolumn{2}{|c|}{$\begin{array}{l}\text { SFO } \\
n=16\end{array}$} & \multicolumn{2}{|c|}{$\begin{array}{l}\text { PHVO } \\
n=3\end{array}$} \\
\hline & $\bar{X} \pm S D$ & Range & $\overline{\mathrm{X}} \pm \mathrm{SD}$ & Range & $\bar{x}_{ \pm} S D$ & Range & $\bar{X}_{ \pm} S D$ & Range \\
\hline $\begin{array}{c}\text { Total } \\
\text { Saturated }\end{array}$ & $17.3 \pm 1.8$ & $12.8-21.4$ & $19.0 \pm 4.7$ & $11.7-27.1$ & $12.8 \pm 1.0$ & $11.9-15.0$ & $22.8 \pm 2.5$ & $24.1-24.5$ \\
\hline $\begin{array}{c}\text { Total } \\
\text { Monounsaturated }\end{array}$ & $24.7 \pm 2.8$ & $21.2-33.0$ & $33.8 \pm 4.6$ & $25.2-40.4$ & $23.5 \pm 2.6$ & $21.0-28.6$ & $71.6^{*} \pm 3.2$ & $69.2-75.2$ \\
\hline $\begin{array}{c}\text { Total } \\
\text { Polyunsaturated }\end{array}$ & $58.0 \pm 3.2$ & $52.4-63.3$ & $47.2 \pm 4.2$ & $37.2-53.0$ & $63.7 \pm 3.4$ & $56.7-67.0$ & $5.6 \pm 0.8$ & $4.8-6.3$ \\
\hline Linoleic & $51.4 \pm 2.8$ & $45.6-55.5$ & $40.9 \pm 3.6$ & $31.9-46.7$ & $63.4 \pm 3.5$ & $56.2-67.0$ & $5.6 \pm 0.8$ & $4.8-6.3$ \\
\hline Linolenic & $6.8 \pm 1.1$ & $3.8-8.7$ & $6.3 \pm 1.1$ & $3.6-8.4$ & $0.3 \pm 0.4$ & $0.0-1.3$ & $0.0 \pm 0.0$ & $0.0-0.0$ \\
\hline
\end{tabular}

SBO, soybean oil; MSBO/CANOLA, mix soybean oil/canola; SFO, sunflower oil; PHVO, partially hydrogenated vegetable oil; ", trans isomers mainly elaidic acid included; total samples, $n=80$.

According to the fatty acid composition, the samples were classified in soybean oils $(S B O) n=39$, mix soybean / canola oils (MSBO/CANOLA) $n=22$, sunflower oils (SFO) $\mathrm{n}=16$ and partially hydrogenated vegetable oils (PHVO) $n=3$.

The vegetable oil most used to prepare french fries potatoes at this small and middle size restaurant and food shop sector, was SBO (49\% of the samples). Moreover, $96 \%$ of the total samples corresponded to highly polyunsaturated vegetable oil. This study was run before the actual Chilean legislation was official at the end of 1997 (Reglamento Sanitario de los Alimentos, Chile, 1997). This regulation established some chemical and physical limitations for frying fatty materials as: maximum $1 \%$ FFA, $1 \%$ oxidized fatty acid insoluble in pethroleum ether or $25 \% \mathrm{CP}$, smoke point not below $170^{\circ} \mathrm{C}$ and also, vegetable oils with more than $2 \%$ linolenic acid were not permitted. Most of the small and middle size restaurants and food shops selected here were using oils not allowed anymore since SBO and MSBO/CANOLA had a linolenic content between $6.3-6.8 \%$ (Table I). France has the same restriction for linolenic acid content, (Firestone, 1996) because high linolenic acid vegetable oils, as rapeseed and soybean, show fast formation of cyclic monomers (Grandgirard, 1987), which are considered risky compounds from the physiological point of view (Kubow 1990).
In relation to the chemical and physical parameters determined to check the deterioration of the different vegetable oils (Table II) the highest value for \% PC was found for MSBO/CANOLA $(21.0 \pm 7.7)$. This indicates an important degree of alteration since the maximum permitted in the present legislation in Chile and other countries is between 25-27\% (Reglamento Sanitario de los Alimentos, Chile, 1997; Firestone, 1996). In the case of SBO and SFO, the mean value for \% PC was lower, around $16 \%$. PHVO gave the lowest value with $10.9 \%$, as expected from its low polyunsaturation degree. The percentages of samples with more than $25 \%$ PC, per type of vegetable oil, were: 18,36 and $19 \%$ for SBO, MSBO/CANOLA and SFO respectively (Table II), and, on average, $23 \%$, lower than that (35\%) found in a similar study (Dobarganes, 1995a). For \% FFA, SFO samples had the highest value (mean of $1 \%$ ), indicating a tendency in this vegetable oil to develop hydrolytic alteration. In general, the increase of \% FFA could be related with the moisture coming from the fresh potatoes but other factors promoting the hydrolitic cleavage of the triglyceride should not be disregarded. $P V$ values were similar in all samples, confirming that it is not a good parameter for deterioration control for heated fats since, during heating hydroperoxide decomposition is faster than accumulation (Stevenson et al., 1984; Al-Kahtani, 1991; Masson et al., 1997). About Vs, MSBO/CANOLA and SBO, 
presented the highest values mainly related to polymerization of linolenic acid, resulting in the formation of high molecular weight compounds (Al-Kahtani 1991). Normal values for Vs in vegetable oils prior to be used for frying french potatoes were around 30-34 ctp (Masson et al., 1997). Finally percentages of CDA representing the formation of conjugated compounds (dienes) due to the shift of the double bond during frying agreed with those reported by Al-Kahtani for oils with high \% PC (Al-Kahtani, 1991).

Table II

Chemical and physical parameters related to fat deterioration per vegetable oil type

\begin{tabular}{|c|c|c|c|c|c|c|c|c|}
\hline & \multicolumn{2}{|c|}{$\begin{array}{c}\text { SBO } \\
n=39\end{array}$} & \multicolumn{2}{|c|}{$\begin{array}{c}\text { MSBO/CANOLA } \\
n=22\end{array}$} & \multicolumn{2}{|c|}{$\begin{array}{l}\text { SFO } \\
n=16\end{array}$} & \multicolumn{2}{|c|}{$\begin{array}{c}\text { PHVO } \\
n=3\end{array}$} \\
\hline & $\bar{X} \pm S D$ & Range & $\bar{X}_{ \pm S D}$ & Range & $\bar{X}_{ \pm} S D$ & Range & $\bar{X} \pm S D$ & Range \\
\hline$\% \mathrm{PC}$ & $16.4 \pm 9.2$ & $3.1-40.3$ & $21.0 \pm 7.7$ & $10.5-35.2$ & $16.1 \pm 7.2$ & $5.3-30.8$ & $10.9 \pm 10.2$ & $3.8-22.6$ \\
\hline$\%$ FFA & $0.58 \pm 0.63$ & $0.07-2.3$ & $0.49 \pm 0.43$ & $0.10-1.58$ & $1.00 \pm 1.4$ & $0.11-5.81$ & $0.27 \pm 0.23$ & $0.06-0.52$ \\
\hline $\mathrm{PV}$ meq/kg & $5.3 \pm 2.4$ & $1.5-13.3$ & $5.60 \pm 1.80$ & $2.5-11.9$ & $4.6 \pm 1.6$ & $2.4-8.3$ & $3.1 \pm 2.1$ & $1.4-5.4$ \\
\hline Vs ctp $-40^{\circ} \mathrm{C}$ & $41.5 \pm 9.7$ & $32.0-80.0$ & $46.2 \pm 7.8$ & $34.0-60.5$ & $36.2 \pm 3.3$ & $32.5-43.0$ & - & - \\
\hline$\% \mathrm{CDA}$ & $1.6 \pm 0.7$ & $0.5-2.9$ & $2.1 \pm 0.6$ & $0.8-2.9$ & $1.4 \pm 0.5$ & $0.8-2.4$ & $0.8 \pm 0.6$ & $0.4-1.5$ \\
\hline
\end{tabular}

SBO, soybean oil; MSBO/CANOLA, mix soybean oil/canola; SFO, sunflower oil; PHVO, partially hydrogenated vegetable oil; \% PC, polar compounds; \% FFA, free fatty acid; PV, peroxide value; Vs, viscosity; \% CDA, conjugated dienoic acids.

With all the experimental data obtained for SBO, MSBO/CANOLA and SFO, statistical analysis and a multiple correlation matrix was approached. The purpose was to compare the methods applied in order to find an easy, suitable one for controlling and predicting deterioration of vegetable oils. Results are shown in Table III. Good correlation coefficients were found between \% PC and Vs, \% CDA and polymers for SBO samples; $r=0.88,0.87$, and 0,94 respectively; and also for polymers with these parameters. Polymers is here the term used for to the sum of triglycelide polymers (TGP) and triglyceride dimers (TGD). These results indicate the relationship existing between total deterioration measured by \% PC and the parameters related with polymerization. In the case of MSBO/CANOLA samples, a good correlation between \% PC, Vs, \% CDA and polymers was also found with $r=0.88$, $0.71,0.91$, respectively.

However SFO samples showed a different pattern, \% PC had a lower correlation coefficient with Vs $(r=0.63)$, polymers $(r=0.51)$ and higher with FFA $(r=0.63)$ compared with SBO and MSBO / CANOLA, confirming the relevant hydrolytic deterioration of SFO samples. These results are not in accordance with those obtained by other author (Arroyo et al., 1992). For PHVO, correlation coefficients were not calculated because the number of samples $(n=3)$ was too small. In other papers, where in vegetable oils were not identified correlation coefficients for $\mathrm{PC}$ with Vs $(0.51 ; 0.63), \%$ PC with \% CDA $(0.63 ; 0.64)$, $\%$ PC with polymers (0.98) and between Vs with \% CDA (0.88) were reported. (Al-Kahtani, 1991; Masson et al., 1997; Sebedio et al., 1987).
Table III

Correlation coefficients and model equations to predict \% PC per vegetable oil type

\begin{tabular}{|c|c|c|c|c|c|}
\hline $\begin{array}{l}\text { Vegetable } \\
\text { oil type }\end{array}$ & Vs & $\%$ CDA & $\% \mathrm{PC}$ & $\%$ FFA & Polymers \\
\hline \multicolumn{6}{|l|}{ SBO } \\
\hline Vs & 1 & & & & \\
\hline$\% \mathrm{CDA}$ & $0.86^{\mathrm{a}}$ & 1 & & & \\
\hline$\% \mathrm{PC}$ & $0.88^{\mathrm{a}}$ & $0.87^{\mathrm{a}}$ & 1 & & \\
\hline$\%$ FFA & 0.18 & 0.17 & 0.38 & 1 & \\
\hline Polymers & $0.91^{\mathrm{a}}$ & $0.87^{\mathrm{a}}$ & $0.94^{\mathrm{a}}$ & 0.14 & 1 \\
\hline$n=39$ & \multicolumn{3}{|c|}{$\% P C=-24+0.99(V s)$} & $p<0.001$ & \\
\hline & \multicolumn{3}{|c|}{$\% P C=-1.04+10.76(\%$ CDA $)$} & $p<0.001$ & \\
\hline \multicolumn{6}{|c|}{ MSBO/CANOLA } \\
\hline Vs & 1 & & & & \\
\hline$\%$ CDA & $0.89^{\mathrm{a}}$ & 1 & & & \\
\hline$\%$ PC & $0.88^{\mathrm{a}}$ & $0.71^{\mathrm{a}}$ & 1 & & \\
\hline$\%$ FFA & 0.31 & 0.20 & 0.34 & 1 & \\
\hline Polymers & $0.78^{\mathrm{a}}$ & $0.62^{\mathrm{b}}$ & $0.91^{\mathrm{a}}$ & 0.08 & 1 \\
\hline \multirow[t]{2}{*}{$n=22$} & \multicolumn{3}{|c|}{$\% P C=-19.3+0.86(V s)$} & $p<0.001$ & \\
\hline & \multicolumn{3}{|c|}{$\% P C=2.67+8.7(\% \mathrm{CDA})$} & $p<0.001$ & \\
\hline \multicolumn{6}{|l|}{ SFO } \\
\hline Vs & 1 & & & & \\
\hline$\% \mathrm{CDA}$ & $0.71^{b}$ & 1 & & & \\
\hline$\% \mathrm{PC}$ & $0.63^{b}$ & 0.36 & 1 & & \\
\hline$\%$ FFA & 0.38 & 0.04 & $0.63^{\mathrm{b}}$ & 1 & \\
\hline Polymers & $0.62^{\mathrm{b}}$ & 0.56 & 0.51 & 0.11 & 1 \\
\hline$n=16$ & \multicolumn{3}{|c|}{$\% P C=-22.9+1.01(V s)+2.37(\% F F A)$} & $\mathrm{p}<0.01$ & \\
\hline
\end{tabular}

SBO, soybean oil; MSBO/CANOLA, mix soybean oil/canola; SFO, sunflower oil; Vs, viscosity; \% CDA, conjugated dienoic acids; \% PC, polar compounds; \% FFA, free fatty acid; Polymers, (TGP + TGD), $a=p<0.001 ; b=p<0.01$. 
As deterioration measured through \% PC needs good laboratory experience and it is time consuming, predicting the content of PC through the equations developed, involving simple and rapid indices (Table III) was very useful as already reported in our previous work (Masson et al., 1997). It is important to emphasize that for SBO and MSBO/CANOLA the parameters considered in the equations were $\mathrm{Vs}$ or $\%$ CDA, but for SFO were Vs and \% FFA.

Polar compounds obtained for each sample were analyzed by SEHPLC, as described in the experimental part, to quantitate different groups of altered species: TGP, TGD, oxTG, DG and FFA. Polimerization compounds (TGP + TGD), normally the predominant group of compounds in used frying fats and oils, were differentiated from oxTG while compounds coming from hydrolysis, DG plus FFA constituted the third group. Figures 1, 2 and 3 show graphically the distribution of these altered species for SBO, MSBO/CANOLA and SFO respectively.
For SBO and MSBO/CANOLA samples, Figs. 1 and 2, respectively, higher tendency to polymerization as compared with hydrolytic alteration was observed. This is consistent with the literature data (Chang et al., 1978, Grandgirard, 1980), in that vegetable oils with substantial levels of linolenic acid are very prone to thermoxidation which supports the limitation established of a maximum of $2 \%$ linolenic acid for DFFP, which excludes SBO, CANOLA and their mixes, (Reglamento Sanitario de los Alimentos, Chile 1997; Firestone, 1996).

In Fig. 3, the distribution of the altered species for SFO is shown. In this case, a higher general tendency for hydrolytic deterioration was observed. The correlation coefficients involving FFA, above commented (Table III) agreed with this different distribution. Percentage of PC and the alteration groups of the three vegetable oils were compared using ANOVA, followed by Duncan test, and results are in Table IV.

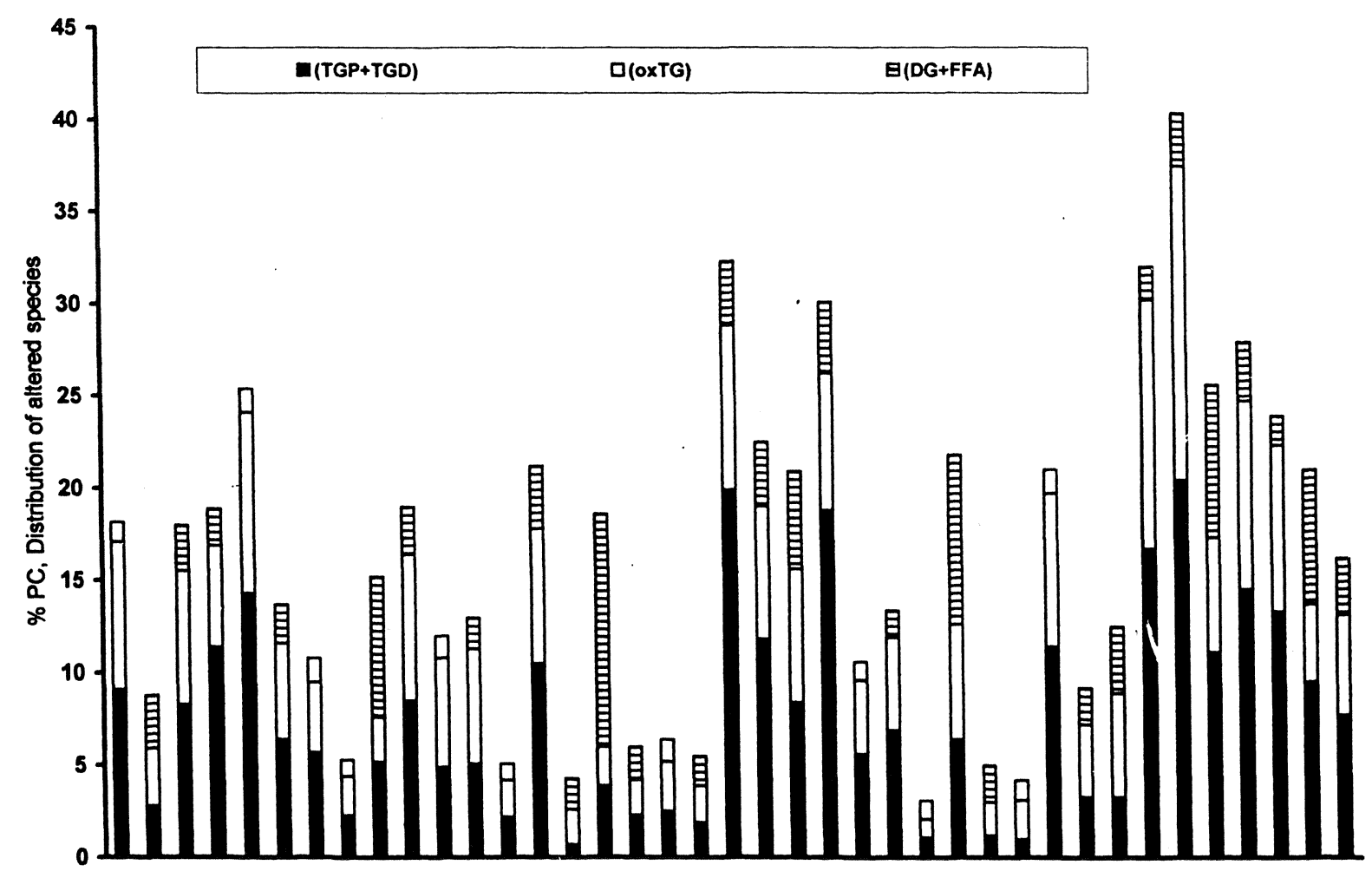

Figure 1

Soybean oil: \% PC, distribution of altered species formed through thermoxidative and hydrolytic reactions.

TGP, Triclycerides polymers; TGD, Triglycerides dimers; oxTG, Oxidized triglyceride monomers; DG, Diglycerides; FFA, Free fatty acids 


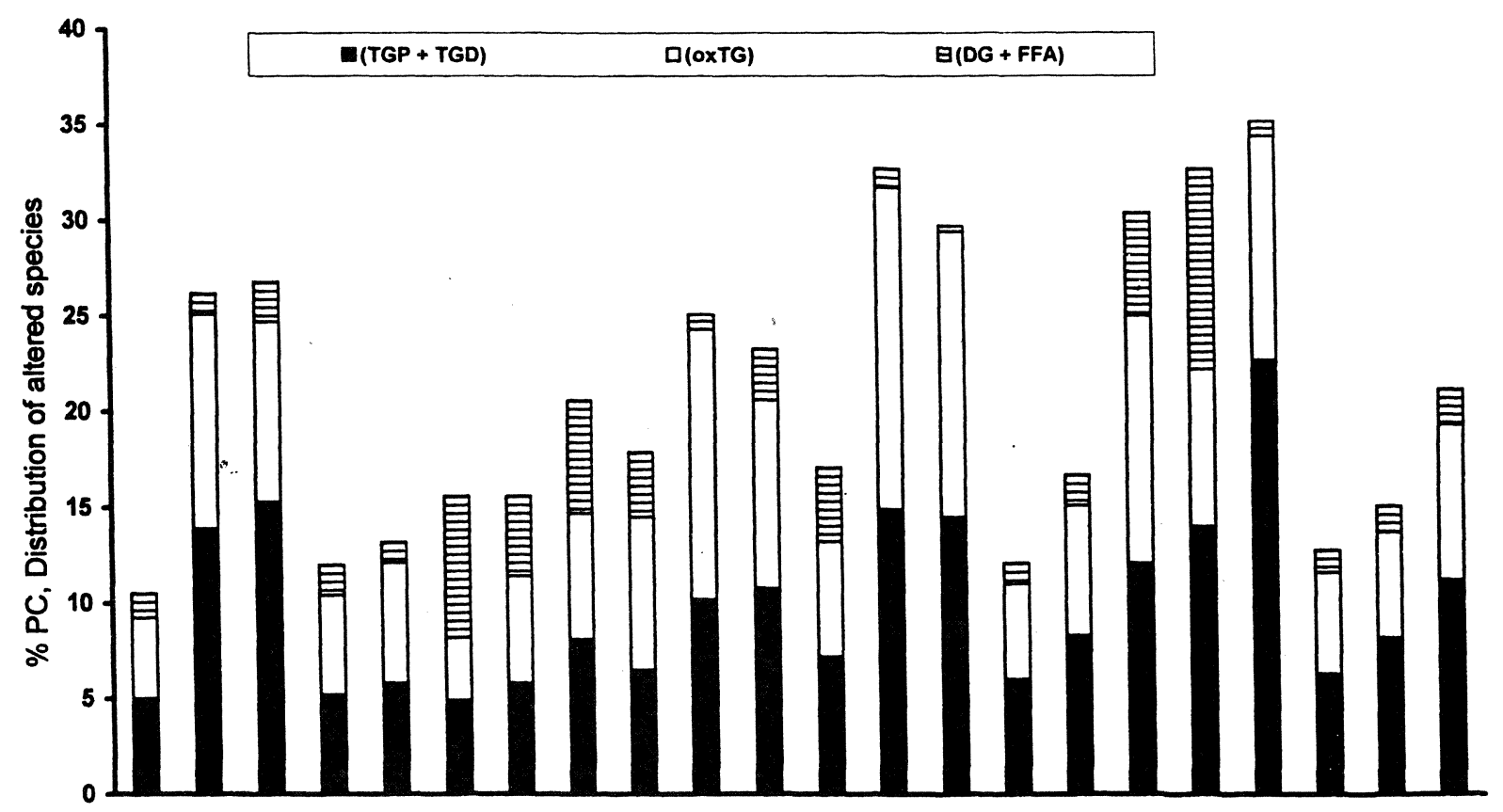

Figure 2

Mix soybean/canola oil: \% PC, distribution of altered species formed through thermoxidative and hydrolytic reactions. TGP, Triclycerides polymers; TGD, Triglycerides dimers; oxTG, Oxidized triglyceride monomers; DG, Diglycerides; FFA, Free fatty acids

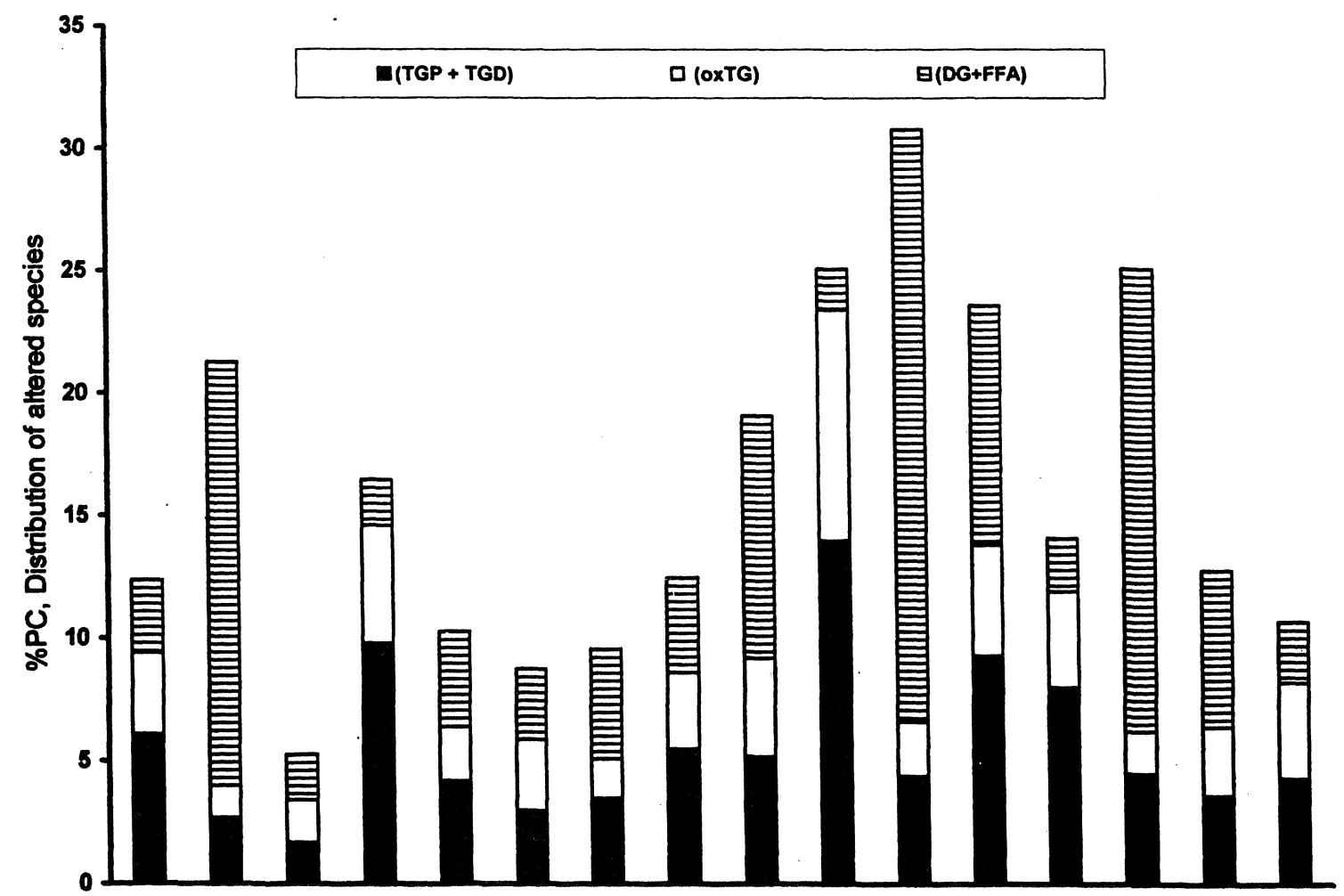

Figure 3

Sunflower oil: \% PC, distribution of altered species formed through thermoxidative and hydrolytic reactions.

TGP, Triclycérides polymers; TGD, Triglycerides dimers; oxTG, Oxidized triglyceride monomers; DG, Diglycerides; FFA, Free fatty acids 
Table IV

Statistical analysis for alteration species per vegetable oil type

\begin{tabular}{ccccc}
\hline Vegetable oil type & \% PC & \% (TGP + TGD) & \% (oxTG) & $\%$ (DG + FFA $)$ \\
\hline & $\begin{array}{c}F(p) 2.54(0.086) \\
\text { no significant }\end{array}$ & $\begin{array}{c}F(p) 3.26(0.044) \\
\text { significant }\end{array}$ & $\begin{array}{c}F(p) ~ 10.34(0.0001) \\
\text { highly significant }\end{array}$ & $\begin{array}{c}F(p) 3.66(0.03) \\
\text { significant }\end{array}$ \\
\cline { 2 - 5 } SBO & 16.4 & Mean & Mean & $3.0 \mathbf{a}$ \\
MSBO/CANOLA & 21.0 & $7.7 \mathbf{a , b}$ & $5.7 \mathbf{b}$ & $2.8 \mathbf{a}$ \\
SFO & 16.1 & $9.8 \mathbf{a}$ & $3.3 \mathbf{c}$ & $7.2 \mathbf{b}$ \\
\hline
\end{tabular}

F, Fisher value; $p$, probability; PC, polar compounds; SBO, soybean oil; MSBO/CANOLA, mix soybean oil/canola; SFO, sunflower oil; different letters mean significant difference among the vegetable oils.

TGP, triglyceride polymers; TGD, triglycerides dimers; oxTG, oxidized triglyceride monomers; DG, diglycerides; FA, free fatty acids.

As expected, the most unsaturated oils, MSBO/ CANOLA and SBO, were the most deteriorated vegetable oils related to thermoxidative alteration. However, in the case of SFO, oxidized and polymeric compounds were significantly lower but unusual predominant hydrolysis occurred. These results are not easy to interpret, given that all samples were submitted practically to similar frying conditions, including the moisture provided by the french fries potatoes. Also it has been generally observed that hydrolysis during frying is not noticeable regardless of the high moisture content of potatoes (Jorge et al., 1996; Romero et al., 1998). It is necessary to emphasize that all the fatty material samples were taken at the moment when french fries potatoes were being prepared without previous notice to the producers. This explains the general variation observed in the results obtained, but, at the same time, data are valuable to give a good idea of the general practice of the frying process at small and middle size restaurant and food shop sector, before the recent Chilean legislation was official.

Oxifrit, Fritest and Perevalov diagnostic kits measure different degrees of deterioration in heated oils by visual estimation of the reaction, against diagnostic color of each kit. Table $\mathrm{V}$ contains the results for quick tests validation: Fritest, Oxifrit and Perevalov per vegetable oil type. The results were divided into right and false for values over and below $25 \%$ PC. In this last group, the results were divided in turn into false positive and false negative in order to evaluate the test confidence. Oxifrit test was the most confidence in all cases, with more than $80 \%$ of right results and low false results for the three vegetable oils identified in this work. False positive results would mean the possibility to discard the oil when its \% PC is still lower than the limit value of $25 \%$. Fritest was the less confidence test, with only $50 \%$ of right results for MSBO/CANOLA and SBO oil. Our results agreed with a previous work (Dobarganes and Márquez-Ruiz, 1995b), where the validity of three quick tests (Perevalov, Veri-fry and Oxifrit) was compared, concluding that Oxifrit test gave the lowest percentage of error. However, in other study carried out with 142 samples, a correlation coefficient of $0.94(p<0.001)$ between Fritest and Oxifrit was obtained (Al-Kahtani et al., 1991).

In conclusion, this study showed that highly polyunsaturated vegetable oils, especially with more than $2 \%$ linolenic acid, seem not suitable to be used in DFFP, such as SBO and MSBO/CANOLA. The determination of \% PC is a good parameter for measuring the total deterioration of the vegetable oil produced by the heating process, and further information can be attained through the distribution of altered species formed. SFO samples showed a different pattern of altered species included in PC, showing a preference to develop hydrolytic over thermoxidative deterioration, as it was the case for SBO and MSBO/CANOLA samples, supporting the recommendation to avoid vegetable oils with more than $2 \%$ linolenic acid for DFFP. The equations developed indicated that selected indices can be used to predict \% PC. Finally Oxifrit test can be recommended as a quick assay «in situ» at small and middle size and food shop restaurant sector, to follow the deterioration of the frying medium. 
Table V

Quik test validation compared with \% PC per vegetable oil type

\begin{tabular}{|c|c|c|c|c|c|c|}
\hline \multirow{2}{*}{ Vegetable oil type } & \multicolumn{2}{|c|}{ Fritest } & \multicolumn{2}{|c|}{ Oxifrit } & \multicolumn{2}{|c|}{ Perevalov } \\
\hline & $\mathrm{n}$ & $\%$ & $\mathrm{n}$ & $\%$ & $\mathrm{n}$ & $\%$ \\
\hline \multicolumn{7}{|l|}{ SBO } \\
\hline TOTAL & 38 & 100 & 38 & 100 & 38 & 100 \\
\hline Right results & 20 & 53 & 33 & 87 & 28 & 74 \\
\hline $\mathrm{PC}<25 \%$ & 13 & 34 & 28 & 74 & 23 & 61 \\
\hline$P C>25 \%$ & 7 & 19 & 5 & 13 & 5 & 13 \\
\hline False results & 18 & 47 & 5 & 13 & 10 & 26 \\
\hline$P C<25 \%$ (false + ) & 18 & 47 & 3 & 8 & 8 & 21 \\
\hline$P C>25 \%$ (false - ) & 0 & 0 & 2 & 5 & 2 & 5 \\
\hline \multicolumn{7}{|l|}{ MSBO/CANOLA } \\
\hline TOTAL & 21 & 100 & 20 & 100 & 19 & 100 \\
\hline Right results & 11 & 52 & 16 & 80 & 12 & 63 \\
\hline $\mathrm{PC}<25 \%$ & 5 & 24 & 12 & 60 & 8 & 42 \\
\hline$P C>25 \%$ & 6 & 28 & 4 & 20 & 4 & 21 \\
\hline False results & 10 & 48 & 4 & 20 & 7 & 37 \\
\hline $\mathrm{PC}<25 \%$ (false + ) & 9 & 43 & 2 & 10 & 6 & 32 \\
\hline PC > $25 \%$ (false -) & 1 & 5 & 2 & 10 & 1 & 5 \\
\hline \multicolumn{7}{|l|}{ SFO } \\
\hline TOTAL & 16 & 100 & 15 & 100 & 15 & 100 \\
\hline Right results & 13 & 81 & 13 & 87 & 12 & 80 \\
\hline $\mathrm{PC}<25 \%$ & 12 & 75 & 13 & 87 & 12 & 80 \\
\hline$P C>25 \%$ & 1 & 6 & 0 & 0 & 0 & 0 \\
\hline False results & 3 & 19 & 2 & 13 & 3 & 20 \\
\hline PC $<25 \%$ (false + ) & 3 & 19 & 1 & 6,5 & 2 & 13 \\
\hline$P C>25 \%$ (false -) & 0 & 0 & 1 & 6,5 & 1 & 7 \\
\hline
\end{tabular}

SBO soybean oil; MSBO/CANOLA, mix soybean oil/canola; SFO, sunflower oil; PC, polar compounds.

\section{ACKNOWLEDGEMENTS}

This work was supported by Grant Fondecyt N ․․ 1950472. We thank S. Valenzuela, V. Carvajal, A. Kulikoff and C. Vilches for laboratory assistance and Dr. R. López Planes for statistical assistance.

\section{BIBLIOGRAPHY}

AENOR, (1991).--Asociación Española de Normalización. Norma UNE 55037-73. Catálogo de Normas UNE, Madrid.

Alexander, J.C. (1978).— «Biological effects due to changes in fats during heating".-J. Am. Oil Chem. Soc. 55, 711-717.

Al-Kahtani, H. (1991).- «Survey of quality of used frying oils from restaurants".-J. Am. Oil Chem. Soc. 68, 857-862.
AOCS (1993)._- OOfficial methods and recomended practices of the American oil Chemists Society". $-3^{\text {th }}$ edition. AOCS, Champaign, Illinois.

Arroyo, R., Cuesta, C., Garrido-Polonio, C., López-Varela, S. and Sánchez-Muniz, F.J. (1992).- «High performance size-exclusion chromatographic studies on polar components formed in sunflower oil used for frying".-J. Am. Oil Chem. Soc. 69, 557-563.

Artman, N.R. (1969).- «The chemical and biological properties of heated and oxidized fats".-Lipid Research, 7, 245-330.

Bender, F., Douglass, L., Kramer, A. (1982).—«Statistical methods for food agriculture".-P. 87, 108, 169. The AVI Publishing Company Inc., Westport (Connecticut).

Billek, G., Guhr, G. and Waibel, J. (1978).- "Quality assessment of used frying fats: a comparison of four methods".-J. Am. Oil Chem. Soc. 55, 728-733.

Combe, N., Constantini, M.J., Entressangles, B. (1978).«Etude sur les huiles chauffées IV. Absorption intestinales des espéces chimiques nouvelles (ECN) formées lors du chauffage des huiles»:-Rev. Fr. Corps Gras. 25, 27-28.

Croon, L.B., Rogstad, A., Leth, T. and Kiutamo, T. (1986).«A comparative study of analytical methods for quality evaluation of frying fat».-Fette Seifen Anstrich. 88, 87-91.

Chang, S.S., Peterson, R.J. and Ho, C.T. (1978)."Chemical reactions involved in the deep-fat frying of foods".-J. Am. Oil Chem. Soc. 55, 718-727.

Dobarganes, M.C. and Pérez-Camino, M.C. (1988)."Fatty acid composition: An useful tool for the determination of deterioration level in heated fats".-Etudes et Recherches, 35, 67-70.

Dobarganes, M.C., Pérez-Camino, M.C. and Márquez-Ruiz, G. (1988).-«High performance size exclusion chromatography of polar compounds in heated and non heated fats".-Fat Sci. Technol. 90, 308-311.

Dobarganes, M.C., Pérez-Camino, M.C., y Márquez-Ruiz, G. (1989).—«Determinación de compuestos polares en aceites y grasas de fritura».-Grasas y Aceites. 40, 35-38.

Dobarganes, M.C. y Márquez-Ruiz, G. (1995a)._-Calidad de las grasas de fritura en el sector de restauración de Andalucía".-Grasas y Aceites. 46, 115-120.

Dobarganes, M.C. y Márquez-Ruiz, G. (1995b).- «Control de calidad de las grasas de fritura. Validez de los métodos de ensayos rápidos en sustitución de la determinación de compuestos polares".-Grasas y Aceites. 46, 196-201.

Firestone, D. (1996). - «Regulation of frying fat and oil» in «Deep Frying: Chemistry, nutrition and practical applications», pp. 323-334. E.G. Perkins and M.D. Erickson (Ed.). American Oil Chemists Society, Champaign, Illinois.

Grandgirard, A. (1980).— - Recherches recentes sur les effects physiologiques de differents types de composés dans les corps gras chauffés".-Ann. Nutr. Aliment. 34, 377-388.

Grandgirard, A. Et Julliard, F. (1987).-«Influence de divers paramèters sur la degradàtion d'huiles végétales au cours du chauffage: nature de l'huile, température et durée du chauffage".-Rev. Fr. Corps Gras. 34, 213-219.

IUPAC (1987). - «Standard Methods for the analysis oils and fats and derivatives". $-7^{\text {th }}$ edition, Pergamon Press, Oxford, England.

Jorge, N., Márquez-Ruiz, G., Martín-Polvillo, M., Ruiz-Méndez, M.V. and Dobarganes, M.C. (1996).- - Influence of 
dimethylpolysiloxane addition to edible oils: dependence on the main variables of the frying process".-Grasas y Aceites 47, 14-19.

Kubow, S. (1990). — «Toxicity of dietary lipid peroxidation products".-Trends in Food Sci. and Technol. September, 67-71.

López-Planes, R. (1994).- «Regresión lineal simple y múltiple. En diseño estadístico de experimentos".(Universidad Autónoma de Yucatán, Universidad de La Habana, Ed.), pp. 107-133, Mérida, Yucatán, México.

Márquez-Ruiz, G., Pérez-Camino, M.C. and Dobarganes, M.C. (1990). - «Combination of adsorption and sizeexclusion chromatography for the determination of fatty and monomers, dimers and polymers".-J. Chromatog. 514, 37-44.

Márquez-Ruiz. G., Pérez-Camino, M.C. and Dobarganes, M.C. (1993).- «Evaluation of hydrolysis and adsorption of thermally oxidized olive oil in non-absorbed lipids in the rat".-Ann. Nutr. Metab. 37, 121-128.

Masson, L., Robert, P., Romero, N., Izaurieta, M. Valenzuela, S., Ortiz, J. y M.C. Dobarganes (1997)."Comportamiento de aceites poliinsaturados en la preparación de patatas fritas para consumo inmediato. Formación de nuevos compuestos y comparación de métodos analíticos".-Grasas y Aceites. 48, 273-281.

Normas Chilenas Oficiales (1978) Nch 43, «Selección de muestra al azar» (sampling random methods) 1994
Nch 44, «Inspección por atributos, tablas y procedimientos de muestreo" (Inspection by atributes, tables and sampling procedures).

Reglamento Sanitario de los Alimentos (1997).Ministerio de Salud. Santiago, Chile.

Romero, A., Cuesta, C. and Sánchez-Muniz, F.J. (1998).«Effect of oil replenishment during deep-fat frying of frozen foods in sunflower oil and high-oleic acid sunflower oil».-J. Am. Oil Chem. Soc. 75, 161-167.

Sebedio, J.L., Grandgirard, A., Septier, Ch. et Prevost, J. (1987). - «Etat d'alteration de quelques huiles de friture préléves en restauration».-Rev. Fr. Corps Gras. 34, 15-18.

Stevenson, S.G., Vaisey-Genser, M. and Eskin, N.A.M. (1984).- -Quality Control in the use of deep frying oils».-J. Am. Oil Chem. Soc. 61, 1102-1108.

Skrökki, A. (1995).- - «ests used for examining the quality of frying oils».-Fat Sci. Technol. 97, 384-386.

Waltking, A.E., and Wessels, H. (1981).- «Chromatographic separation of polar and non-polar components of frying fats».-J. Assoc. Off. Anal. Chem. 64, 1329-1330.

White, P.J. (1991)._ «Methods for measuring changes in deep fat frying oils".-Food Technology. 75-80.

Recibido: Octubre 1998 Aceptado: Febrero 1999 